\title{
37. A MAGNETIC STUDY OF OCEANIC CRUST IN THE VICINITY OF SITES 482, 483, AND 485, LEG 65 ${ }^{1}$
}

\author{
C. N. Hanley, H. P. Johnson, and B. T. R. Lewis, Department of Oceanography and Department of Oceanography \\ and Geophysics Program, University of Washington, Seattle, Washington
}

\section{INTRODUCTION}

During 1975, the proposed site for deep basement drilling on Leg 65 of the Deep Sea Drilling Project (DSDP) was surveyed using the University of Washington ship R/V T.G. Thompson. The survey included magnetic field and bathymetry profiles and a number of dredge hauls of surface rocks from within the site area. Magnetic anomalies were contoured to provide the chronological framework for the drill sites and inverted to determine the distribution of crustal magnetization. Magnetic properties of the dredged surface rocks were measured, and the variation of magnetic intensity compared with the variation in Mid-Atlantic Ridge rocks of the same age and with that in sub-surface rocks drilled in the area during Leg 65. Survey lines and dredge haul locations are shown in Figure 1.

\section{MAGNETIC ANOMALIES}

Figure 2 shows magnetic anomaly patterns superimposed upon the track lines. The total magnetic field was measured using a Geometrics proton precession magnetometer towed three ship lengths behind the vessel. The dash-dot lines indicate the position of the Brunhes/Matuyama boundary and the ridge axis. Figure 3 shows the magnetic anomaly boundaries superimposed on the bathymetry of the region. The median valley is clearly visible along the northern part of the ridge axis. A profile taken along Line 8, shown in Figure 4, shows the welldeveloped median valley topography and the remarkable symmetry associated with the northern ridge crest. Although not obvious at the scale of Figure 5, the southern portion of the ridge also shows magnetic and bathymetric symmetry. These profiles (Lines 6, 4, 2, and 1) are shown, respectively, in Figures 5A-D.

In order to determine the distribution of crustal magnetization away from the axis of the ridge, these profiles were first transformed to the pole by the method described in Blakely and Cox (1972) and then inverted using the techniques of Parker and Huestis (1974). We assumed a two-dimensional magnetic source, uniform directions for the magnetization and field, no vertical variation in magnetization within the crust, and constant thickness of 500 meters for the magnetized layer. The assumption of two-dimensionality near an uncomplicated ridge axis is probably reasonable; the assump-

\footnotetext{
${ }^{1}$ Lewis, B. T. R., Robinson P., et al., Init. Repts. DSDP, 65: Washington (U.S. Govt. Printing Office)
}

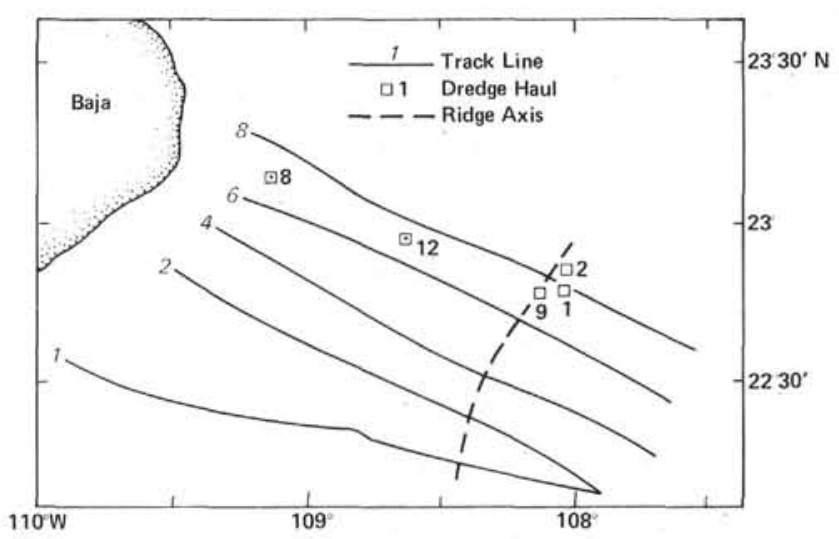

Figure 1. Dredge haul locations and survey track lines in the motth of the Gulf of California (track lines after Lewis et al., this volume).

tions of constant thickness with no vertical magnetic variation are probably less appropriate (Johnson and Merrill, 1978; Johnson, 1978; Ryall et al., 1977; Robinson et al., 1977).

The results of the magnetic anomaly inversions are shown in Figure 4 and in Figures 5A-D. Figure 4 shows the anomaly inversion together with a boomer profile; in Figures $5 \mathrm{~A}-\mathrm{D}$, the inversions are shown with $12 \mathrm{kHz}$ bathymetric records. For comparison, Figure 6 shows a similar magnetic and bathymetric profile taken across the northern Juan de Fuca Ridge at approximately $47^{\circ} \mathrm{N}$ during a 1978 cruise of the T.G. Thompson. Both profiles show the distinctive "five-fingered" shape of the central anomaly, with a rather pronounced magnetic low about $15 \mathrm{~km}$ from the axis over crust that is approximately 0.5 million-years old. Based on similarly shaped anomaly patterns in the Galapagos area, Wilson and Hey (1980) have interpreted this magnetic low as being the result of a magnetic field reversal $0.05 \pm 0.05 \mathrm{~m} . \mathrm{y}$. ago which lasted only about $0.01 \mathrm{~m} . \mathrm{y}$. Champion et al. (1979) and Champion (personal communication) have found reversed polarities in Snake River Plain subaerial lava flows, which have been dated at $0.48 \pm 0.05$ m.y. The similarity of the magnetic anomaly patterns observed across three widely separated mid-ocean ridges, coupled with the paleomagnetic data noted above, suggest that a short magnetic field reversal occurred about 0.5 m.y. ago.

The apparent correlation between the inversion solution and the topography along Line 8 (Fig. 4) was at first believed to have resulted from an alternation be- 


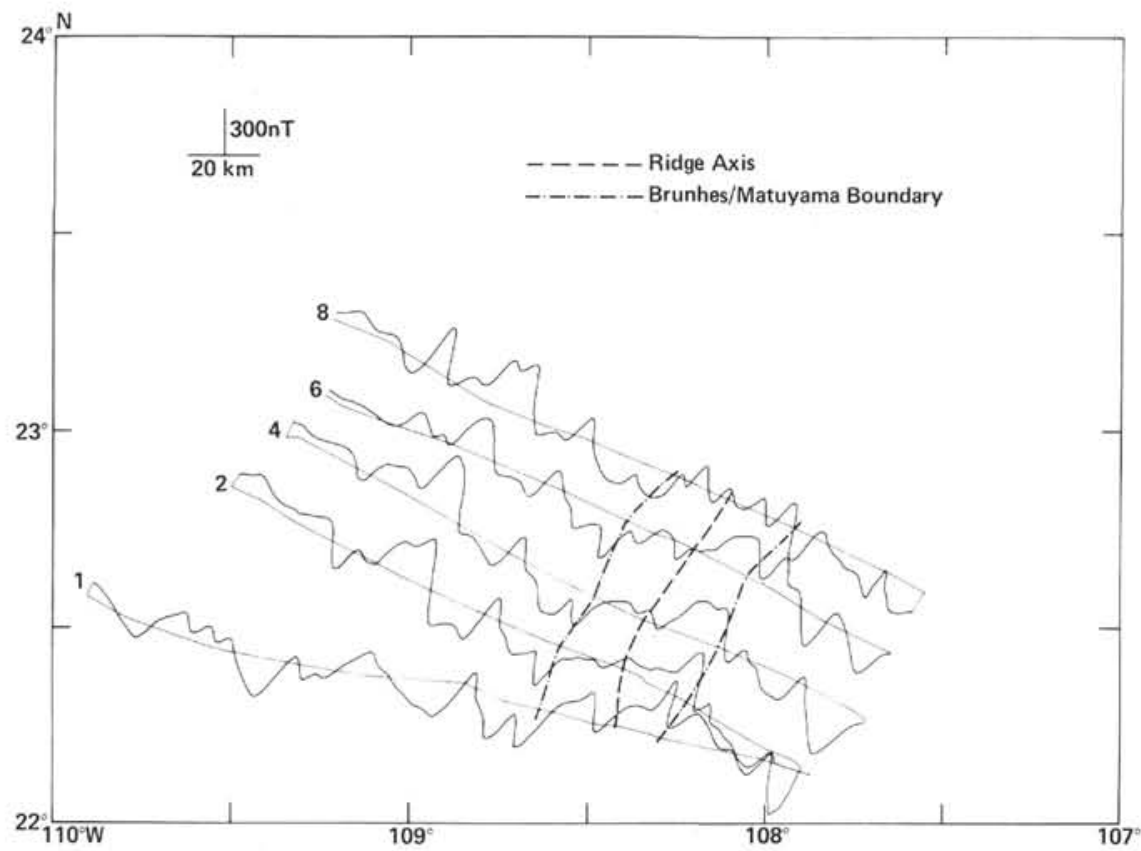

Figure 2. Magnetic anomalies in the mouth of the Gulf of California along survey lines shown in Figure 1.

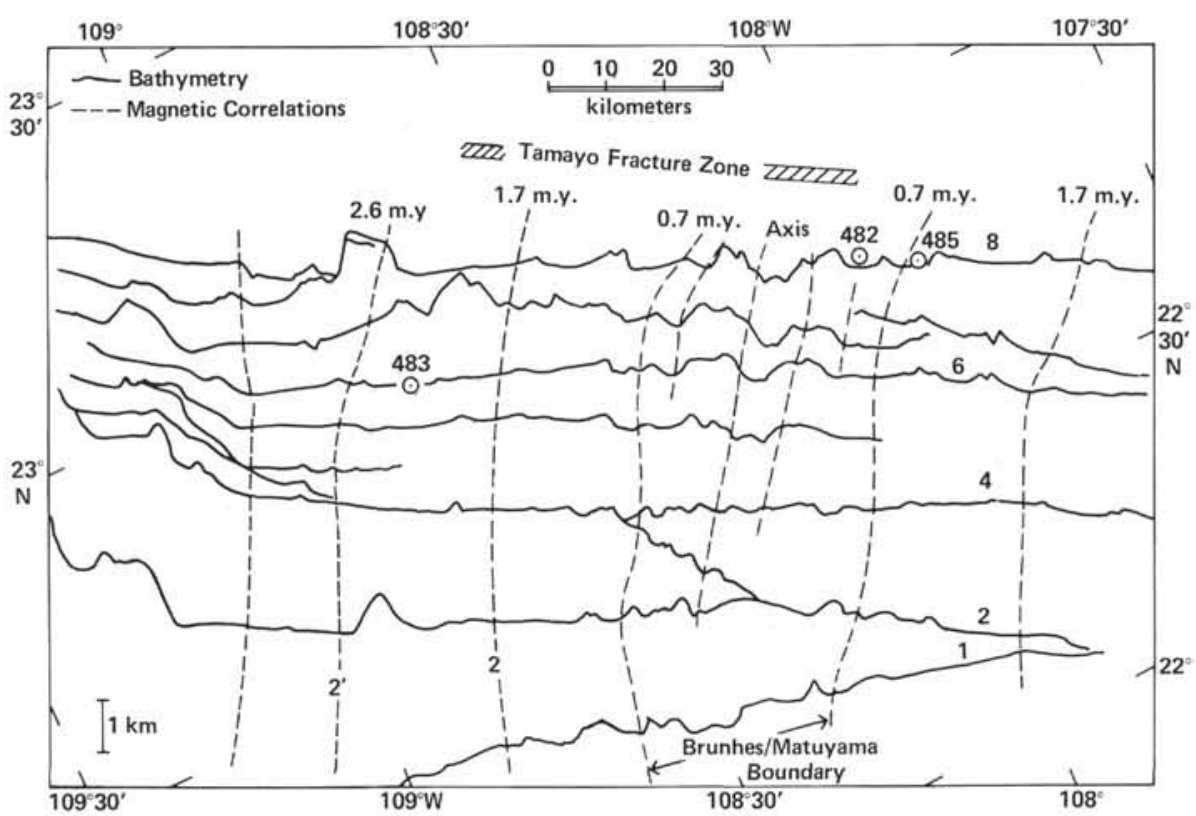

Figure 3. Bathymetry in the mouth of the Gulf of California. (Circles indicate Leg 65 drilling locations.)

tween lava flows and pillow basalts of greater magnetization. However, in looking at Figure 7, Table 1, and Table 2, it appears doubtful that the pillow basalts in the second ridge from the spreading center would be of sufficiently greater magnetization intensity to cause the anomaly. The pillow basalts at Site 482 average 10.8 $\mathrm{A} / \mathrm{m}$, their initially higher magnetization having been decreased by oxidation. Any older pillow basalts would tend to be of equal or lesser intensity. So the dip in both the magnetic anomaly and the topography at $0.5 \mathrm{~m}$.y. is now considered coincidental, similar to the coincidence of the Jaramillo Event and a topographic high between 25 and $30 \mathrm{~km}$ from the axis.

\section{MAGNETIC PROPERTIES OF DREDGED BASALTS}

Rocks dredged from the top of the basement during the site survey can be compared with subsurface samples obtained by drilling in order to see how representative dredged rocks are of the entire vertical section of extrusive basalt. The age variation of the magnetic properties 

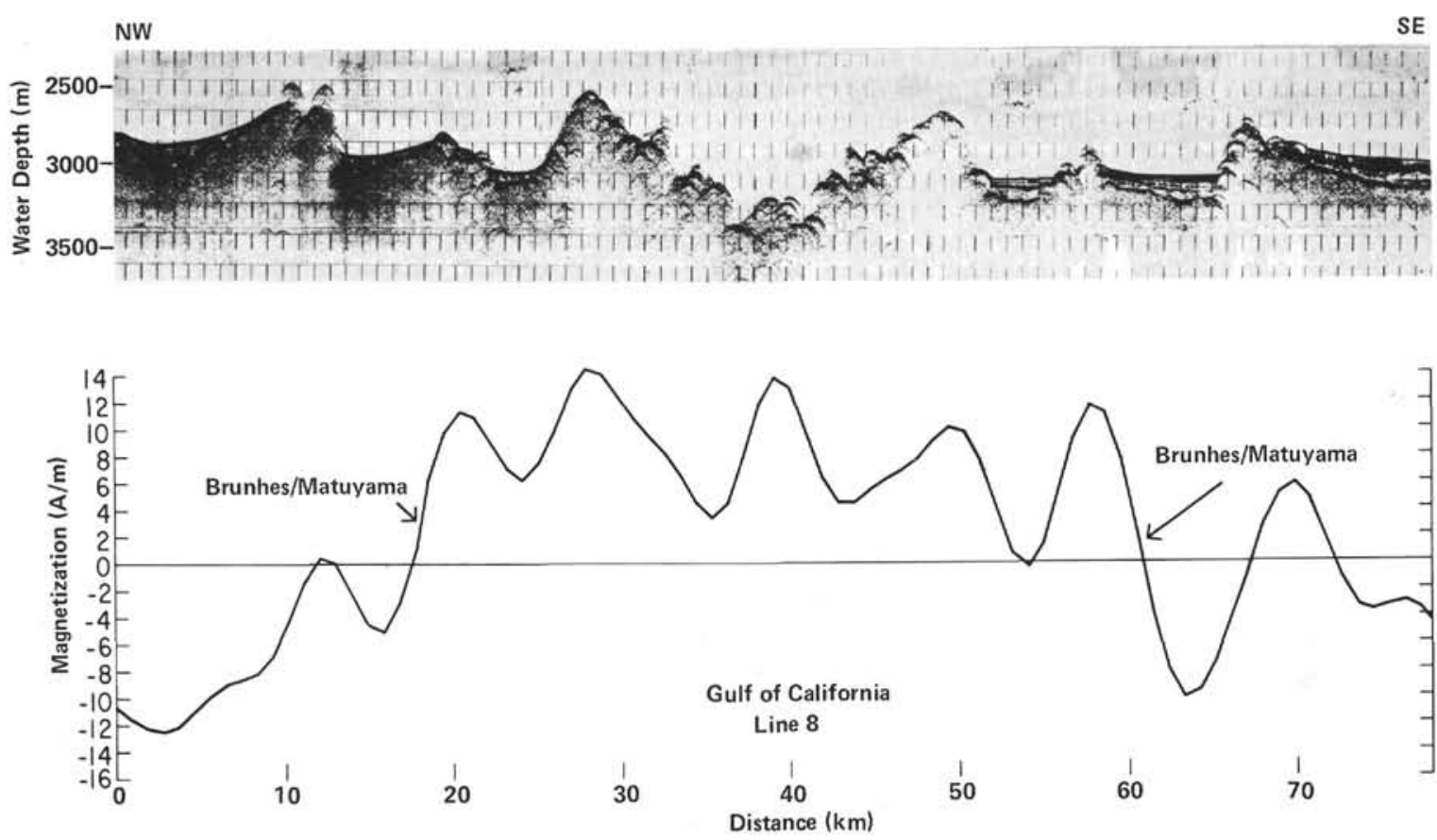

Figure 4. Bathymetry with inversion solution for magnetization along Line 8 in the mouth of the Gulf of California.

of these rocks can also be compared to that of the MidAtlantic Ridge. These comparisons are complicated by the fact that dredging only sampled pillow basalts while the drilling during Leg 65 encountered mostly massive flow units.

The dredge hauls sampled the axial valley, the rise crests, and the ridge flanks as shown in Figure 1. The rocks collected were basaltic pillows with varying degrees of alteration, depending on the age of the site. The ages ranged from very young in the rift valley to about 4 m.y. ago. The natural remanent magnetization (NRM) of the samples was measured using a Schönstedt spinner magnetometer and the NRM intensity values ranged from 0.17 to $36.5 \mathrm{~A} / \mathrm{m}$. (Table 3 ). In order to compare rocks from different latitudes, all of the values are corrected to their equivalent strength at the equator using the relation:

$$
J_{e q} / J_{\theta}=\left(1+3 \sin ^{2} \theta\right)^{-1 / 2} .
$$

The average values shown in Table 1 are from the dredged rocks collected during the site survey, and the values from the drill sites, shown in Table 2, are from Day (this volume) and Day et al. (this volume).

Figure 7 shows the variation of magnetic intensity with age for rocks from the Mid-Atlantic Ridge and for the dredged samples studied here. These values have been compiled from a number of sources, and include samples obtained from dredging and submersible sampling near the Mid-Atlantic Ridge axis (Johnson and Atwater, 1977) and by drilling during DSDP Legs 37 (Ryall et al., 1977), 45 (Johnson, 1978), and 49 (Faller et al., 1979). The ages are determined from magnetic anomalies. The relatively smooth decrease in intensity with age is probably the result of low temperature oxidation of the initial magnetic mineral, titanomagnetite, to titanomaghemite (Irving, 1970; Johnson and Merrill, 1978; Johnson and Atwater, 1977). The best-fit smooth curve through this data is shown in Figure 7 and corresponds to:

$$
J_{N R M}=5.03 \text { (age in m.y.) }{ }^{-0.35}
$$

The following observations may be drawn from a comparison of Tables 1 and 2 with Figure 7.

1) The pillow basalts dredged from the Gulf show a strong decrease in magnetic intensity with increasing age. This decrease is slightly less than, but roughly equivalent to, the decrease observed in Mid-Atlantic Ridge basalts.

2) The massive flow units shown in Table 2 display magnetic intensities that are substantially less than those of very young pillows in Table 1, but they do not show a strong age dependence. This pattern has been observed previously (Johnson and Hall, 1978) in massive basalts, which display a lower initial magnetization than do pillow basalts as a result of their larger magnetic mineral grain size; however, the relatively low permeability of the massive units protects them from the progressive low temperature oxidation that pervades high permeability pillow flows.

3) Although the data are few, a comparison of dredged pillow basalts (Table 1) and subsurface pillows obtained by drilling (Table 2 ) indicates that any initial differences between surface and subsurface pillows (higher magnetization intensity in the surface rocks at $\sim 0.5$ m.y.) is removed by 1.5 to 2.0 m.y. Again, the high permeability of the pillow flows seems to cause pillow basalts throughout the section to be uniformly altered by 1.5 to $2.0 \mathrm{~m}$.y. 

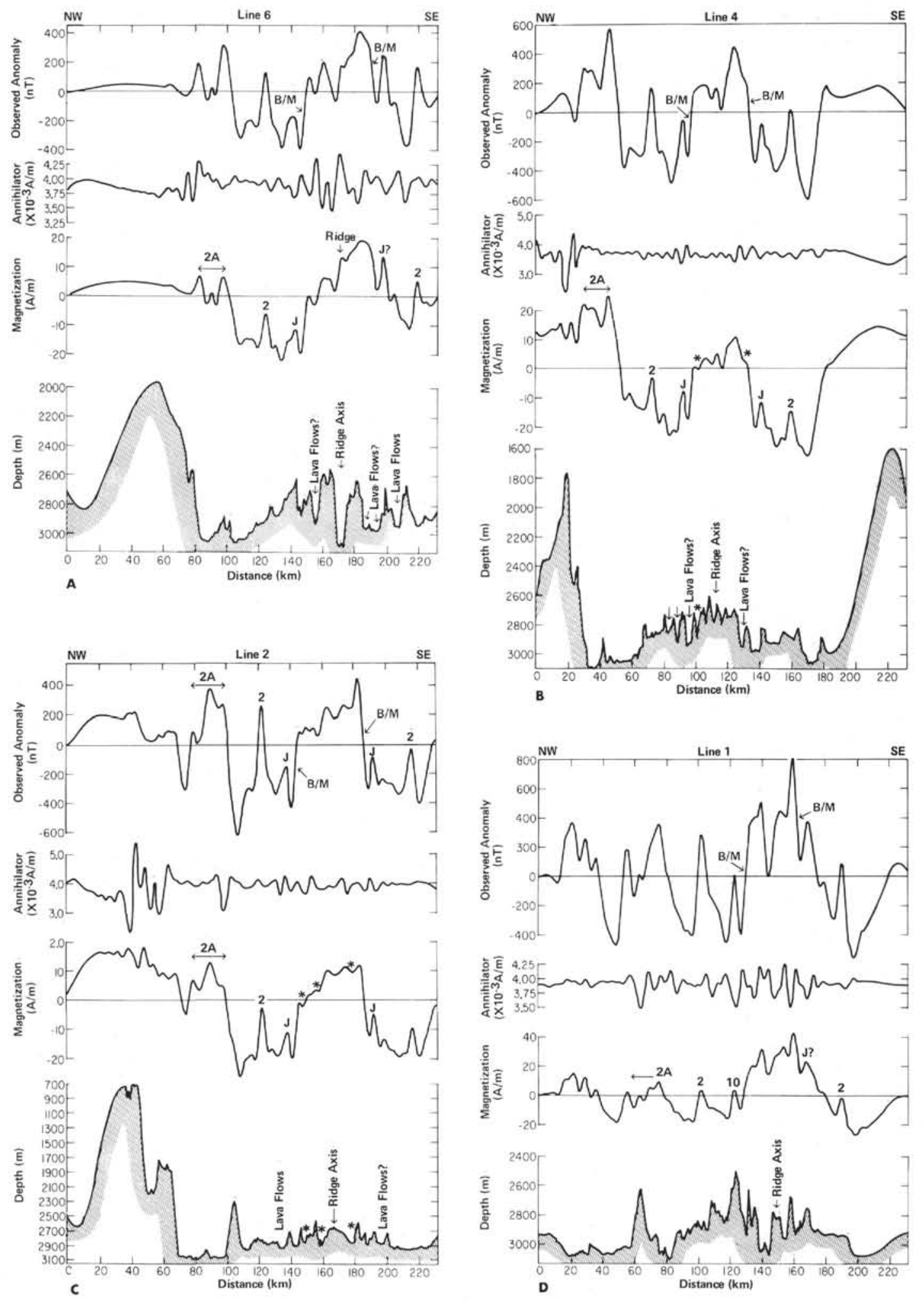

Figure 5. Observed anomaly (top), annihilator, magnetization solution, and bathymetry for Lines 6 (Fig. 5A), 4 (Fig.

5B), 2 (Fig. 5C), and 1 (Fig. 5D), respectively. (B/M = Brunhes/Matuyama boundary; $\mathrm{J}=$ Jaramillo Event; * = points of correlation between magnetization solution and topography.) 

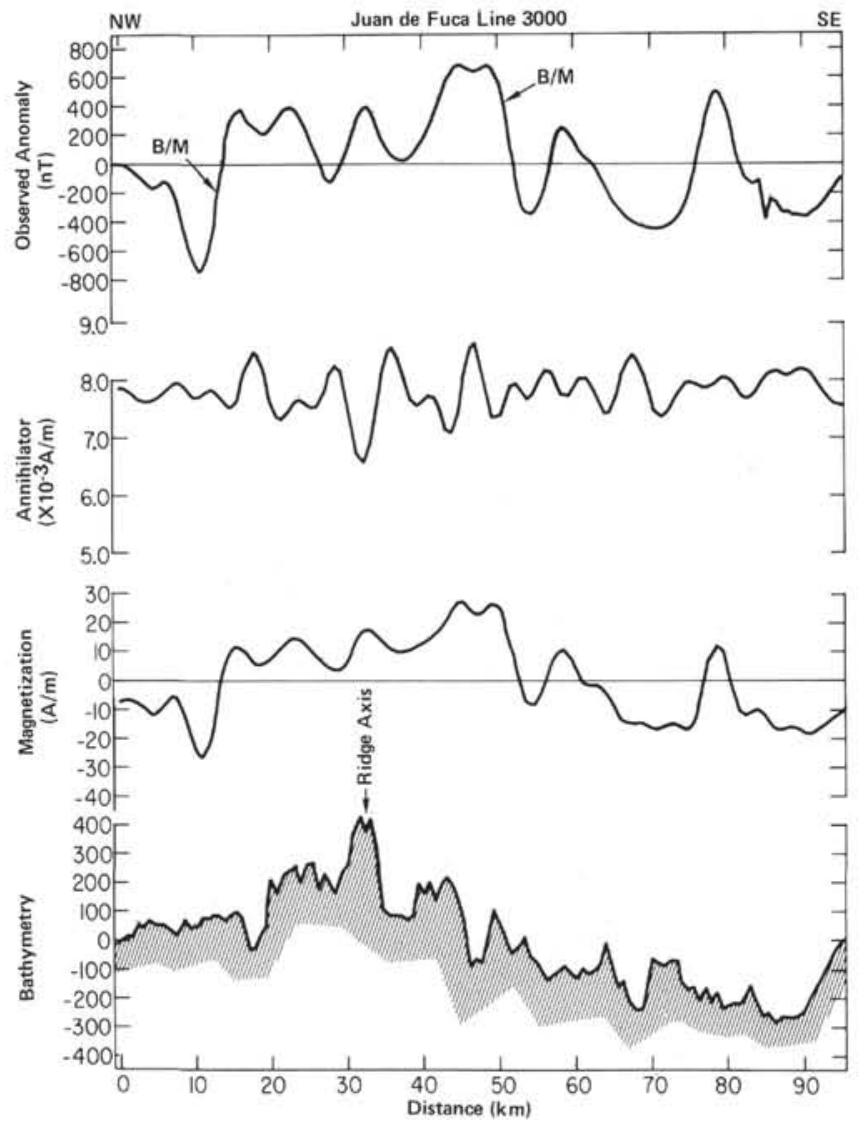

Figure 6. Observed anomaly (top), annihilator, magnetization solution, and bathymetry for Line 3000, Juan de Fuca Rise. (B/M = Brunhes/Matuyama boundary.)

4) The very rapid drop in the intensity of magnetization with age shown in the pillow basalts in Table 1 and more graphically in Figure 7 is very likely responsible for the central magnetic high in the profiles shown in Figures 4 and 6.

\section{ABILITY OF PILLOW BASALTS TO ACQUIRE CHEMICAL REMANENT MAGNETIZATION}

A moderate amount of low temperature oxidation, such as that shown in Figure 7, has been shown to affect dramatically the intensity of remanent magnetization in submarine basalts. The preservation of linear magnetic anomalies over long periods of geologic time argues against substantial directional change of the remanence in these rocks with progressive alteration. Johnson and Merrill (1978) have shown that low temperature oxidation can add a stable chemical remanent magnetization (CRM) component to submarine basalts, although it is substantially less in intensity than the original remanence. Hall (1977) found that for DSDP cores, the scatter in inclination within basalt flows increased from $5^{\circ}$ to as much as $20^{\circ}$ with increasing oxidation.

To test the assumption that no directional change resulted from CRM, the directions of magnetization were determined along cores which were drilled perpendicular to the cooling edge of dredged basalt pillows. The cores were sliced into pieces 1 to $2.5 \mathrm{~cm}$ long and $2.5 \mathrm{~cm}$ in diameter, and the relative declinations and inclinations were measured for each piece. The average change in direction with depth for each core was then averaged for each dredge haul and plotted against age (Fig. 8). Both the average for a dredge haul and the standard deviation increased with age to as much as $9 \pm$ $3^{\circ}$. Thus, both the average directional change in a given core and the possible deviation increase with age. Although a change in direction within a core could be caused by the rotation of the pillow during cooling (Marshall and Cox, 1971), for the amount of change to increase with age, it is most likely that the directional change is the result of a secondary chemical remanent magnetization. While the data shown in Figure 8 should be viewed as preliminary (the samples were not demagnetized), they suggest that at least the highly oxidized pillow basalts obtained by dredging have acquired a chemical remanence.

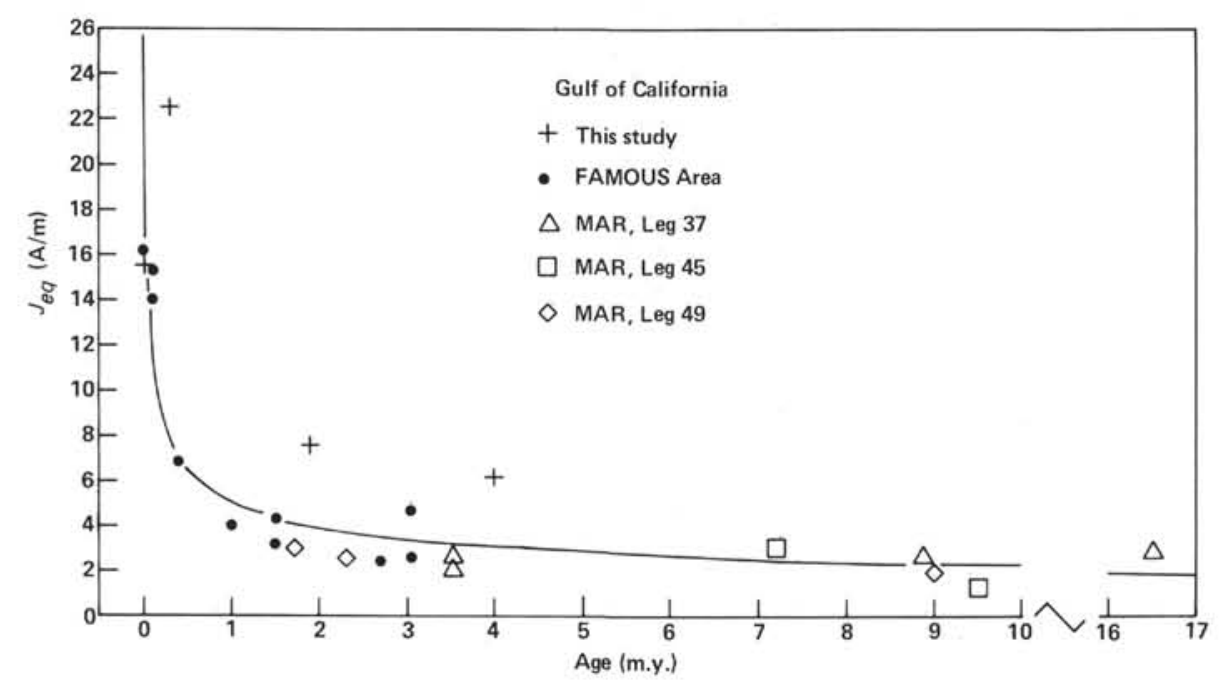

Figure 7. Intensity of magnetization vs. age for basalts from the Atlantic and the Gulf of California. 
Table 1. Natural remanent magnetization of dredged rocks.

\begin{tabular}{|c|c|c|c|}
\hline Site & $\begin{array}{l}\text { Age } \\
\text { (m.y.) }\end{array}$ & $\begin{array}{l}\text { Av. Magnetic } \\
\text { Intensity } \\
(\mathrm{A} / \mathrm{m})\end{array}$ & $\begin{array}{c}\text { No. of } \\
\text { Rock Samples }\end{array}$ \\
\hline $\begin{array}{l}\text { DH09 } \\
\text { Floor of median valley }\end{array}$ & 0.03 & 15.5 & 4 \\
\hline $\begin{array}{l}\text { DH01 } \\
\text { East flank of EPR }\end{array}$ & 0.3 & 22.5 & 9 \\
\hline $\begin{array}{l}\text { DH12 } \\
\text { Seamount west of EPR }\end{array}$ & 1.9 & 7.62 & 7 \\
\hline $\begin{array}{l}\text { DH08 } \\
\text { West of EPR near } \\
\text { continental margin }\end{array}$ & 4.0 & 6.24 & 3 \\
\hline
\end{tabular}

Note: EPR $=$ East Pacific Rise.

Table 2. Natural remanent magnetization of drilled rocks, Leg 65 .

\begin{tabular}{|c|c|c|c|c|}
\hline Site & $\begin{array}{l}\text { Age } \\
\text { (m.y.) }\end{array}$ & $\begin{array}{l}\text { Av. Magnetic } \\
\text { Intensity } \\
(\mathrm{A} / \mathrm{m})\end{array}$ & Polarity & $\begin{array}{c}\text { No. of } \\
\text { Cooling Units }\end{array}$ \\
\hline \multicolumn{5}{|c|}{ Massive Flows } \\
\hline 482 & 0.5 & 7.49 & normal & 13 \\
\hline 485 & 0.74 to 1.2 & 4.17 & mixed & 6 \\
\hline 483 & 1.5 to 2.0 & 6.86 & reversed & 14 \\
\hline \multicolumn{5}{|l|}{ Pillow } \\
\hline 482D & 0.5 & 10.8 & normal & 1 \\
\hline 483 & 1.5 to 2.0 & 7.96 & reversed & 3 \\
\hline
\end{tabular}

Note: Data from Day and Day et al. (both this volume).

\section{CONCLUSIONS}

1. Inversion of the magnetic anomalies observed along both the East Pacific Rise at the mouth of the Gulf of California and the Juan de Fuca Ridge show low crustal magnetization at about 0.5 m.y. This magnetic low, which has been identified on both ridges, is unlikely to be related to alteration or crustal morphology and is thought to reflect magnetic field behavior. It occurs at about the same time as the magnetic field reversal reported by Champion et al. (1979) and by Wilson and Hey (1980) and may be further confirmation of this event.

We note, however, that at Site 482 , only normally magnetized rocks were obtained. Therefore, if our interpretation is correct, the deeper rocks at Site 482 should be reversely magnetized.

2. The NRM intensities of pillow basalts dredged from the seafloor show a strong time dependence, similar to that observed in rocks from the Mid-Atlantic Ridge.

3. The NRM intensities of subsurface pillows drilled during Leg 65 are very similar to those of dredged basalts of equivalent age. This seems to indicate that at least the pillow basalts evolve and alter uniformly with time throughout the vertical section sampled.

4. The massive flows drilled during Leg 65 were initially less magnetic than were unaltered pillows $(\sim 6 \times$ $10^{-3} \mathrm{emu} / \mathrm{cm}^{3}$ ) and the magnetization of these rock units shows no strong time dependence. The difference in the alteration of the pillow basalts and the massive flow units is very likely related to differences in their relative permeability.
Table 3. Natural remanent magnetization of dredged basalts, Leg 65 .

\begin{tabular}{|c|c|c|c|}
\hline Sample No. & $\begin{array}{c}J_{N R M^{\mathrm{a}}} \\
(\mathrm{A} / \mathrm{m})\end{array}$ & $\begin{array}{c}\text { Inclination } \\
\left({ }^{\circ}\right)\end{array}$ & $\begin{array}{c}\text { Declination } \\
\left({ }^{\circ}\right)\end{array}$ \\
\hline \multicolumn{4}{|c|}{$\begin{array}{l}\text { Dredge Haul 9: Slightly weathered basalts, some with } \\
\text { glassy rinds, from } 0.03 \mathrm{~m} . \mathrm{y} \text {. old crust in floor of me- } \\
\text { dian valley. }\end{array}$} \\
\hline $1 /|\mathrm{R}| \mathrm{C}|\mathrm{P}|^{\mathrm{C}}$ & 2.12 & 5.03 & 17.8 \\
\hline R1C1P2 & 10.1 & 8.24 & 13.4 \\
\hline R1CIP3 & 13.3 & 6.89 & 14.8 \\
\hline $\mathrm{R} 1 \mathrm{C} 1 \mathrm{P} 4$ & 11.4 & 8.27 & 16.6 \\
\hline $\mathrm{R} I \mathrm{C} 2 \mathrm{PI}$ & 12.8 & 16.2 & -33.4 \\
\hline \multirow{2}{*}{$\begin{array}{l}\mathrm{R} 1 \mathrm{C} 2 \mathrm{P} 2 \\
\mathrm{R} 1 \mathrm{C} 2 \mathrm{P} 3\end{array}$} & 19.2 & 14.7 & -35.6 \\
\hline & 17.8 & 13.8 & -36.8 \\
\hline R3 P1 & 15.2 & 65.9 & -92.6 \\
\hline P2 & 18.3 & 64.5 & -91.6 \\
\hline P3 & 20.1 & 63.6 & -92.5 \\
\hline R5 & 13.4 & 26.6 & -83.6 \\
\hline P1 & 6.36 & 56.7 & 50.2 \\
\hline $\mathrm{R}_{7}$ & 16.5 & 50.5 & 49.6 \\
\hline Meand & 15.5 & & \\
\hline
\end{tabular}

Dredge Haul 1: Fresh and slightly weathered basalts, some with glassy rinds, from $0.3 \mathrm{~m} . \mathrm{y}$. old crust on east flank of Rise.

$\begin{array}{rrrr}\text { 1/7R5C1P1 } & 29.0 & -24.4 & -17.5 \\ \text { R2C1P4 } & 24.9 & 35.9 & 29.7 \\ \text { R2C2P1 } & 24.2 & 30.1 & 58.0 \\ \text { R2C2P2 } & 21.5 & 30.1 & 59.0 \\ \text { R2C2P3 } & 17.1 & 32.0 & 59.6 \\ \text { Mean } & 22.5 & & \end{array}$

Dredge Haul 12: Basalts from 1.9 m.y old seamount west of Rise.

\begin{tabular}{|c|c|c|c|}
\hline 4/8R4C1P1 & 1.46 & -50.2 & 1.06 \\
\hline $\mathrm{R} 4 \mathrm{ClP}_{2}$ & 7.42 & -54.8 & 7.76 \\
\hline $\mathrm{R} 4 \mathrm{C} 1 \mathrm{P} 3$ & 11.3 & -55.2 & 7.30 \\
\hline $\mathrm{R} 4 \mathrm{C} 1 \mathrm{P} 4$ & 12.3 & -55.7 & 5.32 \\
\hline $\mathrm{R} 4 \mathrm{C} 2 \mathrm{P} 1$ & 6.07 & -55.3 & -18.0 \\
\hline $\mathrm{R} 4 \mathrm{C} 2 \mathrm{P} 2$ & 8.45 & -57.5 & -14.7 \\
\hline $\mathrm{R} 4 \mathrm{C} 2 \mathrm{P} 3$ & 9.28 & -55.4 & -12.9 \\
\hline $\mathrm{R} 4 \mathrm{C} 2 \mathrm{P} 4$ & 10.5 & -56.6 & -12.5 \\
\hline R10C1P1 & 10.2 & -77.4 & 69.4 \\
\hline $\mathrm{R} 10 \mathrm{C} 2 \mathrm{P} 1$ & 3.94 & 79.9 & 3.32 \\
\hline $\mathrm{R} 10 \mathrm{C} 2 \mathrm{P} 2$ & 8.45 & 82.4 & 8.03 \\
\hline $\mathrm{R} 10 \mathrm{C} 2 \mathrm{P} 3$ & 4.80 & 77.9 & 8.03 \\
\hline R10C3P1 & 5.68 & 79.3 & -68.6 \\
\hline $5 / 8 \mathrm{R} 2 \mathrm{C} 1 \mathrm{P} 1$ & 9.94 & 13.5 & 52.0 \\
\hline R2C1P2 & 12.0 & 12.0 & 56.6 \\
\hline $\mathrm{R} 2 \mathrm{C} 1 \mathrm{P} 3$ & 10.7 & 14.6 & 58.4 \\
\hline $\mathrm{R} 2 \mathrm{C} 2 \mathrm{P} 1$ & 2.25 & 25.0 & 12.2 \\
\hline $\mathrm{R} 2 \mathrm{C} 2 \mathrm{P} 2$ & 8.11 & 22.5 & 9.12 \\
\hline $\mathrm{R} 5 \mathrm{C} 1 \mathrm{P} 2$ & 27.0 & -23.1 & -15.8 \\
\hline R5C2P1 & 26.3 & 15.1 & -21.4 \\
\hline $\mathrm{R} 5 \mathrm{C} 2 \mathrm{P} 2$ & 23.7 & 17.6 & -10.4 \\
\hline R7C1P1 & 7.57 & -37.2 & -49.5 \\
\hline $\mathrm{R} 7 \mathrm{C} 1 \mathrm{P} 2$ & 13.8 & -35.9 & -47.7 \\
\hline $\mathrm{R} 7 \mathrm{C} 2 \mathrm{P} 1$ & 5.39 & -57.5 & -78.8 \\
\hline $\mathrm{R} 7 \mathrm{C} 2 \mathrm{P} 2$ & 7.24 & -48.5 & -85.6 \\
\hline $\mathrm{R} 8 \mathrm{C} 1 \mathrm{P} 1$ & 27.1 & -24.8 & 64.6 \\
\hline $\mathrm{R} 8 \mathrm{C} 2 \mathrm{PI}$ & 19.8 & -19.1 & 59.2 \\
\hline $\mathrm{R} 8 \mathrm{C} 2 \mathrm{P} 2$ & 23.2 & -15.8 & 62.8 \\
\hline $\mathrm{R} 8 \mathrm{C} 2 \mathrm{P} 3$ & 24.4 & -15.2 & 61.6 \\
\hline $3 / 7 \mathrm{R} 1 \mathrm{ClPl}$ & 5.66 & 27.4 & -79.3 \\
\hline $\mathrm{R} 1 \mathrm{C} 1 \mathrm{P} 2$ & 27.6 & 26.4 & -76.6 \\
\hline $\mathrm{R} 1 \mathrm{C} 2 \mathrm{P} 1$ & 26.7 & -63.9 & 45.7 \\
\hline $\mathrm{R} 1 \mathrm{C} 2 \mathrm{P} 2$ & 29.1 & -62.7 & 49.6 \\
\hline $\mathrm{R} 1 \mathrm{C} 2 \mathrm{P} 3$ & 27.1 & -62.7 & 50.4 \\
\hline $\mathrm{R} 1 \mathrm{C} 3 \mathrm{P} 1$ & 28.5 & -30.7 & 72.2 \\
\hline $\mathrm{R} 1 \mathrm{C} 3 \mathrm{P} 2$ & 28.4 & -29.3 & 75.8 \\
\hline 4/7R1ClPl & 9.55 & -21.8 & -31.2 \\
\hline $\mathrm{R} 1 \mathrm{C} 1 \mathrm{P} 2$ & 30.3 & -20.6 & -38.9 \\
\hline $\mathrm{R} 1 \mathrm{C} 1 \mathrm{P} 3$ & 30.3 & -21.2 & -34.1 \\
\hline $\mathrm{R} 1 \mathrm{C} 1 \mathrm{P} 4$ & 24.6 & -21.5 & -34.4 \\
\hline $\mathrm{R} 1 \mathrm{C} 2 \mathrm{P} 1$ & 19.2 & 78.3 & 2.29 \\
\hline $\mathrm{R} 1 \mathrm{C} 2 \mathrm{P} 2$ & 21.3 & 77.5 & 12.7 \\
\hline 5/7R1C1P1 & 25.6 & -23.6 & 54.4 \\
\hline
\end{tabular}


Table 3. (Continued).

\begin{tabular}{|c|c|c|c|}
\hline Sample No. & $\begin{array}{c}J_{N R M^{\mathrm{a}}} \\
(\mathrm{A} / \mathrm{m})\end{array}$ & $\begin{array}{c}\text { Inclination } \\
\left({ }^{\circ}\right)\end{array}$ & $\begin{array}{c}\text { Declination } \\
\left({ }^{\circ}\right)\end{array}$ \\
\hline 5/7R5C1P2 & 26.7 & -21.5 & 57.9 \\
\hline R5C2P1 & 12.2 & -36.1 & -55.6 \\
\hline $\mathrm{R} 5 \mathrm{C} 2 \mathrm{P} 2$ & 24.4 & -31.9 & -52.5 \\
\hline R6C1P1 & 23.8 & -26.5 & -35.3 \\
\hline $\mathrm{R} 6 \mathrm{CIP} 2$ & 26.8 & -24.6 & -31.7 \\
\hline $\mathrm{R} 6 \mathrm{CIP} 3$ & 24.0 & -22.6 & -31.0 \\
\hline $\mathrm{R} 6 \mathrm{C} 2 \mathrm{P} 1$ & 21.9 & -29.4 & -89.9 \\
\hline $\mathrm{R} 6 \mathrm{C} 2 \mathrm{P} 2$ & 26.1 & -28.8 & -89.7 \\
\hline $\mathrm{R} 6 \mathrm{C} 2 \mathrm{P} 3$ & 21.9 & -27.4 & -88.9 \\
\hline $\mathrm{R} 6 \mathrm{C} 3 \mathrm{P} 1$ & 23.1 & -27.9 & 12.2 \\
\hline $\mathrm{R} 6 \mathrm{C} 3 \mathrm{P} 2$ & 24.2 & -28.9 & 10.7 \\
\hline R6C3P3 & 23.0 & -29.9 & 8.62 \\
\hline $6 / 7 \mathrm{R} 7 \mathrm{C} 1 \mathrm{Pl}$ & 25.5 & 44.6 & -21.2 \\
\hline $\mathrm{R} 7 \mathrm{C} 1 \mathrm{P} 2$ & 27.0 & 45.6 & -22.1 \\
\hline R7C1P3 & 27.9 & 46.4 & -19.4 \\
\hline R7C1P4 & 29.3 & 46.7 & -19.1 \\
\hline $\mathrm{R} 7 \mathrm{C} 2 \mathrm{P} 1$ & 3.59 & 22.9 & -15.5 \\
\hline $\mathrm{R} 7 \mathrm{C} 2 \mathrm{P} 2$ & 31.1 & 25.3 & -8.03 \\
\hline R7C2P3 & 29.3 & 25.3 & -5.33 \\
\hline 7/7R2C1P1 & 17.9 & 32.1 & 31.2 \\
\hline $\mathrm{R} 2 \mathrm{C} 1 \mathrm{P} 2$ & 22.7 & 33.1 & 30.1 \\
\hline $\mathrm{R} 2 \mathrm{C} 1 \mathrm{P} 3$ & 27.2 & 35.3 & 31.0 \\
\hline $\mathrm{R} 2 \mathrm{C} 2 \mathrm{P} 3$ & 9.69 & 25.0 & 10.3 \\
\hline 6/8R7C1P1 & 5.51 & 16.6 & -27.8 \\
\hline R7C1P2 & 5.64 & 15.8 & -30.6 \\
\hline $\mathrm{R} 7 \mathrm{C} 1 \mathrm{P} 3$ & 1.88 & 13.0 & -32.0 \\
\hline $\mathrm{R} 7 \mathrm{C} 1 \mathrm{P} 4$ & 4.05 & 11.2 & -27.7 \\
\hline R7C3P1 & 5.94 & -66.4 & -74.2 \\
\hline $\mathrm{R} 7 \mathrm{C} 3 \mathrm{P} 2$ & 6.20 & -63.9 & -66.0 \\
\hline 7/8R1C1P1 & 0.986 & -3.64 & -70.0 \\
\hline $\mathrm{R} 1 \mathrm{C} 1 \mathrm{P} 2$ & 4.80 & -8.15 & -68.1 \\
\hline R1C1P3 & 5.55 & -10.3 & -68.9 \\
\hline R1C1P4 & 7.13 & -10.5 & -69.2 \\
\hline R1C1P5 & 8.45 & -7.27 & -70.6 \\
\hline $\mathrm{R} 1 \mathrm{C} 2 \mathrm{P} 1$ & 2.18 & -21.5 & 29.8 \\
\hline $\mathrm{R} 1 \mathrm{C} 2 \mathrm{P} 2$ & 4.91 & -21.6 & 35.1 \\
\hline $\mathrm{R} 1 \mathrm{C} 2 \mathrm{P} 3$ & 5.87 & -21.0 & 31.0 \\
\hline 8/8RICIP1 & 9.28 & 49.2 & -73.9 \\
\hline $\mathrm{R} 1 \mathrm{C} 1 \mathrm{P} 2$ & 13.7 & 50.7 & -71.8 \\
\hline R1C1P3 & 12.3 & 50.2 & -79.4 \\
\hline $\mathrm{R} 1 \mathrm{C} 2 \mathrm{P} 1$ & 13.8 & 45.8 & -21.2 \\
\hline $\mathrm{R} 1 \mathrm{C} 2 \mathrm{P} 2$ & 13.3 & 49.3 & -22.4 \\
\hline R1C2P3 & 12.7 & 49.1 & -26.1 \\
\hline $\mathrm{R} 12 \mathrm{C} 1 \mathrm{P} 1$ & 1.76 & -31.1 & -78.5 \\
\hline $\mathrm{R} 12 \mathrm{C} 1 \mathrm{P} 2$ & 4.82 & -28.6 & 76.2 \\
\hline R12C1P3 & 3.29 & -23.4 & -76.3 \\
\hline Mean ${ }^{\mathrm{d}}$ & 7.62 & & \\
\hline
\end{tabular}

Dredge Haul 8: Weathered basalts from 4.0 m.y. old crust near continental margin.

\begin{tabular}{rccr} 
1/9R2C1P1 & 4.91 & -29.4 & -54.0 \\
R2C1P2 & 14.4 & -29.4 & -54.3 \\
R2C1P3 & 17.9 & -29.2 & -56.8 \\
R2C2P1 & 17.2 & -41.0 & 46.2 \\
6/9R1C1P1 & 0.361 & -3.98 & -69.3 \\
R1C1P2 & 0.542 & -1.82 & -67.5 \\
R1C2P1 & 0.178 & 42.3 & 46.2 \\
R1C3P1 & 0.143 & 32.5 & -87.8 \\
R1C3P2 & 0.671 & 40.9 & -78.6 \\
R1C3P3 & 0.506 & 37.1 & -81.4 \\
R6C1P1 & 1.67 & 4.91 & -57.9 \\
R6C1P2 & 1.97 & -24.2 & -60.5 \\
R6C1P3 & 2.25 & -9.13 & -59.8 \\
R6C2P1 & 1.18 & -12.0 & 89.1 \\
R6C2P2 & 1.48 & -16.0 & 87.5 \\
R6C2P3 & 2.45 & -33.7 & 82.7 \\
R6C2P4 & 1.73 & -14.6 & 85.0 \\
Mean & 7.53 & & \\
\hline
\end{tabular}

a Corrected to value at equator.

b Relative to core axis (samples unoriented).

c $1 / 1=1$ st sack of $1 ; \mathrm{R} 1=1$ st rock in sack; $\mathrm{Cl}=$ 1 st core from rock; $\mathrm{P} 1=1$ st piece of core (usually closest to cooling edge).

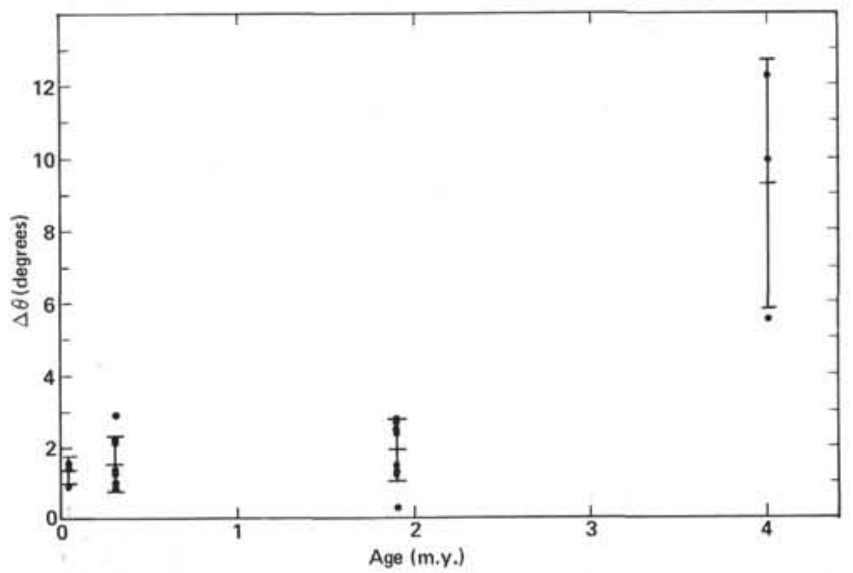

Figure 8. Change in direction of magnetization with age in basalt pillows from the Gulf of California.

\section{REFERENCES}

Blakely, R. J., and Cox, A., 1972. Identification of short polarity events by transforming marine magnetic profiles to the Pole. $J$. Geophys. Res., 77:4339-4349.

Champion, D., Dalrymple, B., Kuntz, M., Doherty, D., 1979. Reversed polarity lava flows within a late Pleistocene volcanic sequence from Snake River Plain, Idaho: A possible reversed event within the Brunhes Normal Polarity Epoch. EOS, 60:814.

Faller, A. M., Steiner, M., and Kobayashi, K., 1979. Paleomagnetism of basalts and interlayered sediments drilled during DSDP Leg 49 (N-S transect of the northern Mid-Atlantic Ridge). In Luyendyk, B. P., Cann, J. R., et al., Init. Repts. DSDP, 49: Washington (U.S. Govt. Printing Office), 769-780.

Hall, J. M., 1977. Does TRM occur in oceanic Layer 2 basalts? J. Geomag. Geoelectr., 29:411-419.

Irving, E., 1970. The Mid-Atlantic Ridge at $45^{\circ} \mathrm{N}$. IIV. Oxidation and magnetic properties of basalt: Review and discussion. Can. J. Earth Sci., 7:1528-1538.

Johnson, H. P., 1979. Paleomagnetism of igneous rock samples-Leg 45. In Melson, W. G., Rabinowitz, P. D., et al., Init. Repts. DSDP, 45: Washington (U.S. Govt. Printing Office), 407-420.

Johnson, H. P., and Atwater, T., 1977. Magnetic study of basalts from the Mid-Atlantic Ridge, lat. $37^{\circ} \mathrm{N}$. Geol. Soc. Am. Bull., 88:637-647.

Johnson, H. P., and Hall., J. M., 1978. A detailed rock magnetic and opaque mineralogy study of the basalts from the Nazca Plate. Geophys. J.R. Astron. Soc., 52:45-64.

Johnson, H. P., and Merrill, R. T., 1978. Low-temperature oxidation of a titanomagnetite and the implications for paleomagnetism. $J$. Geophys. Res., 78:4938-4949.

Marshall, M., and Cox, A., 1971. Magnetism of pillow basalts and their petrology. Geol. Soc. Am. Bull., 82:537-552.

Parker, R. L., and Huestis, S. P., 1974. The inversion of magnetic anomalies in the presence of topography. J. Geophys. Res., 79: $1587-1593$.

Robinson, P. T., Hall, J. M., and Leg 37 Shipboard Scientific Party, 1977. Leg 37 cruise synthesis: The lithology, structure, petrology and magnetic history of Layer 2. In Aumento, F., Melson, W. G., et al., Init. Repts. DSDP, 37: Washington (U.S. Govt. Printing Office), 987-997.

Ryall, P. J. C., Hall, J. M., Clark, J., and Milligan, T., 1977. Magnetization of ocean crustal Layer 2-Results and thoughts after Leg 37. Can. J. Earth Sci., 14:684-706.

Wilson, D. S., and Hey, R. N., 1980. A new reversal during the Brunhes and other implications of the fine structure of the axial magnetic anomaly, Galapagos Spreading Center. EOS, 61:GP26. 